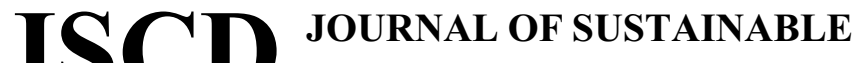

p-ISSN: 2715-5080

\section{Pendekatan Green Eco Tourism Berbasis Budaya dalam Memajukan Pariwisata Bahari}

\author{
Amelia Naim Indrajaya ${ }^{1 *}$, Evita Sukmawati ${ }^{2}$, \\ Clemence Perrin ${ }^{3}$, Wiwiek Mardawiyah Daryanto ${ }^{4}$ \\ ${ }^{1,4}$ Sekolah Tinggi Ilmu Ekonomi Indonesia Jakarta, 13320 \\ ${ }^{2}$ Matias Rasul Saint, Jakarta \\ ${ }^{3}$ Audencia Business School, 44312 Nantes, France \\ Author E-mail: amelia.naim@ipmi.ac.id
}

\begin{abstract}
A B S T R A K
Kepulauan Seribu merupakan tujuan pariwisata yang amat terkenal dan masih merupakan bagian dari propinsi DKI jaya. Banyak wisatawan yang memilih berlibur ke Kepulauan Seribu karena letaknya yang dekat dari ibu kota. Pulau Kelapa ini adalah pulau tempat terdamparnya para pelaut dari Sulawesi Selatan sejak tigapuluh lima tahun yang lalu. Rumah-rumahnya masih berupa rumah panggung tradisional Bugis dengan kondisi yang kumuh, meskipun menyimpan potensi kebaharian yang tinggi. Program Pengabdian Masyarakat ini bertujuan untuk mengembangkan potensi Eco Tourism di Pulau Kelapa. Hal ini dimungkinkan juga karena Kementrian Lingkungan Hidup dan Kehutanan mempunyai kantor Taman Laut di pulau ini. Kegiatan pengabdian masyarakat ini menggali kekuatan, kelemahan, potensi serta juga berupaya untuk menggalang usaha swadaya masyarakat terutama dalam meningkatkan mutu pelayanan yang menunjang kegiatan pariwisata berwawasan lingkungan yang ada di Pulau Kelapa. Kegiatan ini telah menunjukkan hasil dan diharapkan dapat memberikan sustainable impact pada masyarakat kepulauan.
\end{abstract}

Kata Kunci: Kepulauan Seribu, Eco Tourism, Online Marketing, pariwisata berwawasan lingkungan.

\section{A B S T R A C T}

The thousand island is a favorite destination for marine life tourism. It is chosen because of its location which is close to the capital city, only a couple of hours from Jakarta. Kelapa Dua island is a small island in the thousand island archipelago. More than 30 years ago the brave fishermen from Bugis sailed across the ocean from South Sulawesi and some of them settled in this Kelapa dua island area. Typical houses of Kelapa Dua are traditional Bugis stilt wooden house still far from the high quality sanitation standard. This island has a potential for Eco Tourism. This is possible because it has the turtle conservation run by the Ministry of Environment and Forestry. This paper analyze the strength, weakness of Kelapa Dua island and collaborate with Kinarya Corporation which developed a movie on Kelapa Dua island. This community engagement program is designed to improve service excellence of the local communities to ensure sustainability in implementing Eco-tourism in Kelapa Dua Island.

Keywords: Service Excellence, Thousand Island, Eco tourism, Online Marketing, Marine Eco Tourism. 


\section{PENDAHULUAN}

Pulau Kelapa termasuk yang tertinggal dibanding pulau-pulau lainnya di kepulauan Seribu. Pulaupulau lain sudah dijalankan oleh pebisnis tingkat tinggi bahkan dioperasikan dengan mengandalkan turis-turis dari golongan menengah atas dari dalam negeri dan turis-turis dari luar negeri. Sementara pulau Kelapa dihuni sebagian besar oleh para nelayan. Lebih dari 35 tahun yang lalu, para pelaut yang gagah berani dari Sulawesi Selatan mengarungi Nusantara untuk mencari penghidupan yang lebih baik. Sebagian dari mereka terdampar di pulau Kelapa ini. Namun sayangnya upaya untuk mencari penghidupan yang lebih baik masih belum tercapai, karena masyarakat di pulau ini umumnya adalah nelayan dan sebagian adalah nelayan buruh yang bekerja di keramba-keramba ikan di tengah laut milik para pengusaha.

Tempat tinggal mereka masih berupa rumahrumah panggung sederhana dari kayu. Sampai saat ini masyarakat masih menjalankan adat istiadat asli Bugis yang dibawa dari Sulawesi Selatan. Bahasa dan tatacara sehari-hari pun masih kental berbau Bugis. Setiap tahun ada pula perayaan hari Syukuran Laut yang masih dijalankan dari generasi ke generasi.

Melihat kondisi yang menyedihkan ini para relawan menggalang sebuah koperasi yang dinamakan koperasi Kinarya untuk membantu mengangkat kehidupan para nelayan di Pulau Kelapa . Remaja-remaja yang tergabung di Kinarya mengangkat kisah perayaan syukuran laut dan kisah para nelayan ini dalam sebuah filem dengan judul Impian Seribu Pulau yang sangat menyentuh. Pendekatan inovasi melalui filem ini diharapkan dapat membuka mata para penonton akan keberadaan pulau Kelapa sehingga dapat menjadi destinasi wisata seperti yang terjadi pada pulau Belitung melalui filem Laskar Pelangi nya.

Filem yang mengangkat kehidupan di Pulau Kelapa diharapkan dapat mengenalkan pulau Kelapa Dua kepada khalayak ramai. Kantor kementrian lingkungan hidup yang mengurusi taman laut berlokasi di pulau ini. Di pulau ini ditemukan pula berbagai sarana untuk melakukan kegiatan berbasis wisata edukasi alam seperti penangkaran penyu, penanaman mangrove, pembudidayaan terumbu karang, namun masih harus dikembangkan agar dapat menjadi destinasi wisata bahari berwawasan lingkungan. Filem Impian Seribu Pulau dapat memotivasi pelancong untuk datang, namun untuk dapat mengangkat kehidupan para nelayan di Kelapa Dua, maka para pelancong yang datang setelah menyaksikan filem tersebut perlu mendapatkan pelayanan yang berkualitas dari komunitas yang menghuni pulau Kelapa. Ini mencakup aspek pelayanan dan kemampuan berbahasa Inggris dan berbahasa asing lainnya.

Masalah yang dihadapi oleh pulau Kelapa terutama adalah masalah sumber daya manusia. Di sini hanya tersedia Pendidikan Anak Usia dini dan Taman Kanak-Kanak sementara untuk melanjutkan pendidikan maka anak-anak harus pergi ke pulau seberang. Masalah lainnya adalah masalah kebersihan. Sampah berserakan, serta rumah-rumah dibangun dari bahan-bahan daur ulang yang terkesan seadanya. Hal utama lainnya adalah tiadanya fasilitas seperti rumah makan dan penginapan. Ini semua mengakibatkan pulau Kelapa belum menjadi sasaran untuk tujuan pariwisata.

Pengabdian masyarakat ini diharapkan dapat menunjang kegiatan pariwisata di kelapa dua melalui melalui peningkatkan kualitas para pemandu wisata dan local champion Pulau Kelapa. Hal ini dilakukan dengan memperkenalkan kepada pemandu wisata setempat konsep pelayanan kepada turis mancanegara serta kiat menerapkan pendekatan eko-tourisme. Selain itu program pendampingan ini bertujuan untuk menganalisa potensi untuk mengembangkan model dan strategi untuk meningkatkan aktivitas pariwisata yang ada di Pulau Kelapa sehingga dapat dikenal sebagai destinasi wisata berwawasan lingkungan. Program pengabdian masyarakat ini diharapkan dapat berdampak dengan semakin meningkatnya wisatawan yang berkunjung ke Pulau Kelapa. 
Di pulau Kelapa ini terdapat beberapa keunikan yang dapat menjadi daya tarik bagi pengunjung untuk datang. Di sini ada perusahaan pembesaran ikan Bawal Putih. Perusahaan ini berasal dari Jepang dan unik karena hanya ada di Pulau Kelapa ini. Ikan Bawal Putih ini sangat terkenal. Selain unik juga beratnya dapat mencapai lebih dari 15 kilogram. Seperti yang telah disinggung sebelumnya di sini juga ada penangkaran penyu yang dijalankan oleh Kantor Pengelola Taman Laut di bawah Kementrian Lingkungan dan Kehutanan. Di pulau ini juga tengah dikembangkan hutan mangrove dan terumbu karang. Juga ada beberapa tempat yang instagrammable karena digunakan sebagai tempat shooting filem Impian Seribu Pulau.

Selain keunikan yang disebutkan di atas. Pulau Kelapa juga unik karena merupakan tempat tinggal bagi warga yang berlatar belakang budaya Bugis. Rumah panggung yang berderet-deret di pulau seluruhnya merupakan rumah panggung bergaya Bugis. Begitu pula adat istiadat di pulau ini masih dilaksanakan secara turun menurun. Contohnya upaya tahunan syukuran laut serta ritual budaya lain yang berasal dari budaya Bugis serta masih diterapkan dalam kehidupan seharihari. Ini semua adalah hal-hal unik yang dapat menjadi daya tarik bagi wisatawan dalam maupun luar negeri.

Dari pengamatan langsung di lapangan terlihat bahwa fasilitas yang tersedia adalah tempat ibadah Masjid AL-Janatun Na'im, sekolah Paud dan Taman Kanak Kanak, tempat pengolah water treatment / osmosis yang merupakan sumber air bersih kedua bagi warga Pulau Kelapa setelah air hujan, serta Taman Nasional.

Ada beberapa poin of interest yang dapat menarik minat para wisatawan: Acara tahun syukuran laut yang fenomenal, yang dilakukan sebagai wujud rasa syukur warga pulau akan hasil tangkapan laut yang telah disediakan Allah Yang Maha Kuasa; Budaya suku Bugis, dan rumah panggung yang merupakan ciri khas suku Bugis; Posisi pulau Kelapa yang amat strategis baik untuk mengamati matahari terbit maupun matahari terbenam; Di pulau Kelapa tersedia penangkaran penyu, pembudidayaan koral dan penanaman mangrove; Di depan penangkaran penyu, terdapat juga pojokan yang menyediakan alat-alat permainan tradisional, sehingga wisatawan dapat menikmati berbagai permainan tradisional yang sudah langka dan cukup mengasyikkan.

Semua poin-poin keunikan di atas berpotensi untuk mendatangkan wisatawan bila pemandu setempat serta komunitas penyedia jasa pelayanan di pulau Kelapa mampu meramunya menjadi pengalaman berwisata bahari berbasis lingkungan dan budaya yang berkesan.

\section{METODE PELAKSANAAN}

Sasaran pembangunan yang berkelanjutan yang dicanangkan oleh Perserikatan Bangsa Bangsa menetapkan 17 sasaran yang harus dicapai oleh semua warga dunia. Oleh sebab itu kini tengah diminati program wisata berbasis lingkungan, yang bertujuan untuk mendukung program sasaran pembangunan yang berkelanjutan atau yang biasa disebut sebagai The Sustainable Development Goals of the United Nation (SDG of the UN). Khususnya program pengembangan pariwisata bahari di pulau Kelapa mendukung sasaran no 14 yang mendukung kehidupan bawah laut, serta sasaran nomor 1 yang mengangkat isu memberantas kemiskinan. Kedua SDG ini adalah dua poin utama yang dapat didukung dengan mengembangkan potensi wisata di pulau Kelapa ini.

Pemerintah juga sedang mencanangkan pentingnya melestarikan keasrian lingkungan yang sering dikampanyekan oleh Kementrian Lingkungan dan Kehutanan. Pulau Kelapa ini adalah bagian dari Taman Nasional Kepulauan Seribu. Di pulau ini kantor Taman Nasional juga dilengkapi dengan sarana penangkaran penyu, serta berbagai program pengembangan seperti pengembangan koral, penanaman mangrove yang semuanya berwawasan lingkungan. Dengan semua fasilitas yang tersedia, ini menjadi tanggung jawab moral bagi kita untuk menggalakkan promosi untuk Eko tourisme karena erat kaitannya 
dengan pengembangan obyek daya tarik wisata alam (Kasim, 2006 dalam Feronika, 2011).

Program yang perlu dikembangkan adalah program wisata berbasis alam bahari yang ramah lingkungan. Program ini bertujuan agar penduduk menjadi teredukasi mengenai konsep wisata ramah lingkungan serta juga mampu berinteraksi dengan wisatawan mancanegara yang datang berkunjung. Tujuan dari pelaksanaan program pengembangan komunitas pemandu wisata kepulauan seribu ini adalah selain untuk meningkatkan kualitas lingkungan, juga mengedukasi penduduk serta turis-turis yang berkunjung mengenai pentingnya partisipasi dalam memelihara lingkungan. Program pengembangan sumber daya pemandu wisata berorientasi wisata bahari berwawasan lingkungan ini diharapkan dapat memberikan kesempatan dan lapangan pekerjaan kepada lebih banyak lagi bagi pegiat komunitas lokal dengan lebih meningkatnya daya tarik pulau Kelapa sebagai tujuan daerah pariwisata berbasis eko wisata (Andini, 2013).

Kegiatan pengabdian kepada masyarakat (Abdimas) ini dilaksanakan oleh dosen dibantu oleh para mahasiswa melalui observasi langsung, interview serta pelaksanaan program-program berbasis masyarakat. Langkah-langkah yang dilakukan adalah sebagai berikut:

1. Observasi langsung mengenai kehidupan, dan analisa situasi sebelum menjalankan program pengabdian masyarakat.

2. Bekerja sama dengan Koperasi Kinarya yang menggandeng para remaja setempat untuk memproduksi filem Impian Seribu Pulau. Kerjasama ini dilakukan dengan turut serta melatih para sineas muda mengenai pentingnya mendukung Sasaran Pembangunan Berkelanjutan melalui filem, sehingga para penonton dapat memperoleh sudut pandang baru untuk turut serta dalam memelihara sumber daya alam.

3. Wawancara dengan tokoh setempat: Para tetua kampung, para pelaut yang merintis perjalanan awal dari Sulawesi Selatan sehingga akhirnya terdampar dan bermukim di pulau Kelapa.

4. Wawancara dengan para pemuda setempat. Mencoba menggali aspirasi dari para pemuda pemudi setempat.

5. Wawancara dengan komunitas ibu-ibu UMKM yang menjajakan produknya pada wisatawan yang mampir ke pulau Kelapa.

6. Memetakan masalah dari berbagai sumber.

7. Melakukan Analisa Akar Masalah dan ditemukan salah satu faktor adalah ketidak siapan para penduduk lokal untuk menyediakan sarana yang menarik minat wisatawan, juga perlunya keahlian menyambut dan melayani para wisatawan.

8. Melakukan Focus Group Discussion untuk memastikan bahwa pendekatan yang dipilih sudah sesuai dengan apa yang dibutuhkan oleh masyarakat pulau Kelapa.

9. Mengadakan pelatihan di pulau Kelapa. Para pemandu wisata diperkenalkan dengan konsep "Service Excellence" yang memberikan kemampuan untuk memberikan pelayanan yang memuaskan serta memberikan pemahaman mengenai pariwisata ramah lingkungan dengan konsep Eco Tourisme melalui wisata menanam terumbu karang, menanam mangrove, serta budidaya penyu. Dan memperkenalkan juga konsep pariwisata berbasis budaya.

10. Memberikan contoh-contoh model penguatan pariwisata bahari yang dapat disesuaikan dengan pulau Kelapa.

11. Memberikan pelatihan mengenai pemasaran dan promosi online serta kiat untuk meningkatkan promosi paket turis melalui paket turis secara online dan melalui sosial media.

Dalam kurun waktu kurang lebih satu semester dilakukan empat kali kunjungan dengan dua kali kunjungan yang dilakukan dalam bentuk pelatihan. Dari hasil obsertasi, wawancara dan focus group discussion dilakukan suatu Analisa SWOT (Strength, Weaknesses, Opportunity and Threat) sebagai berikut:

\section{a. Strenght (Kekuatan)}


- Kebudayaan yang unik (Bugis) serta terpelihara secara asri secara turun menurun. Ritual-ritual yang masih dijalankan sampai saat ini termasuk acara tahunan fenomenal syukuran laut yang diselenggarakan secara besar-besaran setiap tahun.

- Saat ini sudah mempunyai sarana eko tourisme yang memadai, dalam bentuk penangkaran penyu, budidaya koral dan penanaman mangrove.

- Penduduk lokal mempunyai kemauan belajar yang tinggi dan mereka mau belajar sesuatu hal yang baru termasuk mengenal bahasa asing serta membuka diri untuk perubahan.

b. Weaknesses (Kelemahan)

- Di pulau Kelapa belum tersedia penginapan serta rumah makan yang nyaman dan memadai untuk wisatawan. Pada saat wisatawan berkunjung ke Pulau Kelapa, mereka mau tidak mau akan mencari penginapan di pulau lain.

- Masih rendahnya tingkat edukasi penduduk lokal mengenai konsep eco-tourism serta bagaimana cara mengelola industri pariwisata secara baik.

- Masyarakat setempat belum memahami aktivitas marketing secara baik, untuk memasarkan Pulau Kelapa.

Selain dilakukan analisa kekuatan dan kelemahan, perlu juga dilakukan analisa kesempatan dan ancaman.

\section{c. Opportunity (Kesempatan)}

- Generasi muda lebih memilih experience di banding menumpuk asset. Saat ini dengan bonus demografi, maka Indonesia memiliki populasi generasi usia produktif yang lebih besar. Ini adalah market yang sangat besar untuk industri pariwisata.

- Konsep pariwisata berbasis budaya dan lingkungan bahari adalah konsep yang unik, serta masih langka bagi sebuah paket pariwisata yang menawarkan kebudayaan yang juga memiliki pendekatan eco tourism di kawasan DKI Jakarta, khususnya di wilayah di kepulauan Seribu.
- Kemajuan social media yang memudahkan orang untuk bisa memasarkan produk dengan lebih mudah, murah dan cepat.

\section{d. Threats (Ancaman)}

- Ancaman datangnya dari paket turis di pulaupulau lain yang sudah lebih tertata dengan baik.

- Waktu tempuh yang cukup lama dan relative mahal untuk perjalanan ke Pulau Kelapa.

Dari hasil triangulasi, pengamatan, wawancara serta focus group discussion yang kemudian dilakukan analisa SWOT (Strength, Weaknesses, Opportunity dan Threat) maka dilakukan beberapa pendekatan dalam pelaksanaan pengabdian masyarakat ini. Pendekatan abdimas dilakukan melalui program pengabdian masyarakat di pulau Kelapa sebagai berikut:

1. Memberikan beberapa masukan dan bisnis model yang dapat diterapkan di pulau Kelapa.

2. Melakukan beberapa sesi pelatihan untuk mengembangkan Sumber Daya Manusia Pulau Kelapa.

3. Mengenalkan Pemasaran Online untuk menawarkan pariwisata dan kuliner kelapa dua.

\section{HASIL DAN PEMBAHASAN}

Dengan mengamati hasil triangulasi dari observasi, hasil wawancara serta focus group discussion maka kami mengajukan beberapa masukan bisnis model yang dapat memberikan ide baru yang berdampak positif terhadap pariwisata di pulau. Adapun hasil kegiatan yang telah dilaksanakan sesuai dengan rancangan atau rencana kegiatan a dalah sebagai berikut:

\section{Membuat "Kompetisi RT dengan Rumah Panggung Terbersih"}

Sebuah kiat untuk dapat memotivasi penduduk agar selalu memperindah dan memastikan kebersihan tempat tinggalnya, adalah melalui kompetisi. Kompetisi dapat diikuti oleh ke tiga RT yang ada di Pulau. Pemenang akan mendapat piala serta penghargaan akan diumumkan di Balai Pertemuan untuk menjadi kebanggaan bersama. 
Kebersihan merupakan hal penting bagi wisatawan saat berkunjung ke sebuah tempat wisata.

\section{Merapihkan Rumah Panggung dan Guest House}

Di Pulau ini tidak terdapat penginapan yang memadai, oleh sebab itu hanya dijadikan tempat persinggahan. Namun hanya di pulau inilah sebenarnya terdapat fasilitas penangkaran penyu, pembudidayaan koral serta penanaman mangrove. Oleh sebab itu diperlukan terobosan, misalnya, upaya agar merapihkan rumah-rumah panggung ini, sehingga menjadi berseri. Misalnya, ini dapat dilakukan dengan meniru terobosan sejenis yang telah lebih dahulu ada, seperti yang terlihat di foto di bawah ini. Perlu pula disediakan Guest House di Pulau Kelapa namun dengan tetap mempertahankan ciri khas Bugis sebagai keunikannya.

Ide warna-warni yang berseri ini terinspirasi dari beberapa tujuan pariwisata yang telah ada dan menjadi viral karena daya Tarik keunikannya, seperti rumah warna warni di Malang (Lihat gambar 1)

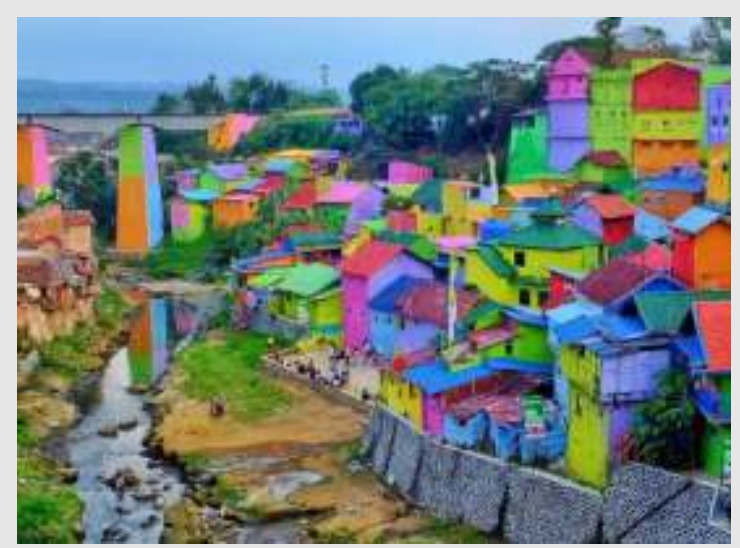

Gambar 1. Ide rumah warna-warni di Malang

\section{Mengembangkan Restauran Yang Lebih Berkualitas}

Untuk dapat memberikan kepuasan pelayanan pada wisatawan maka hal yang penting adalah pada penyajian makanan yang memberikan kesan istimewa. Untuk mencapai hal ini diperlukan pendampingan dari restoran dan ahli tata boga, agar penduduk dapat menguasai ketrampilan seni boga dan juga cara penyajiannya, meskipun tetap harus bernuansa Bugis.

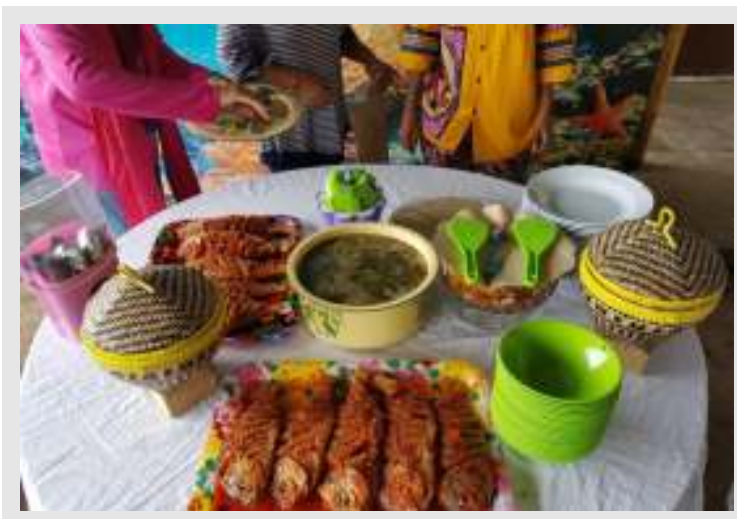

Gambar 2. Menu Makan Siang di Kelapa Dua Saat Ini

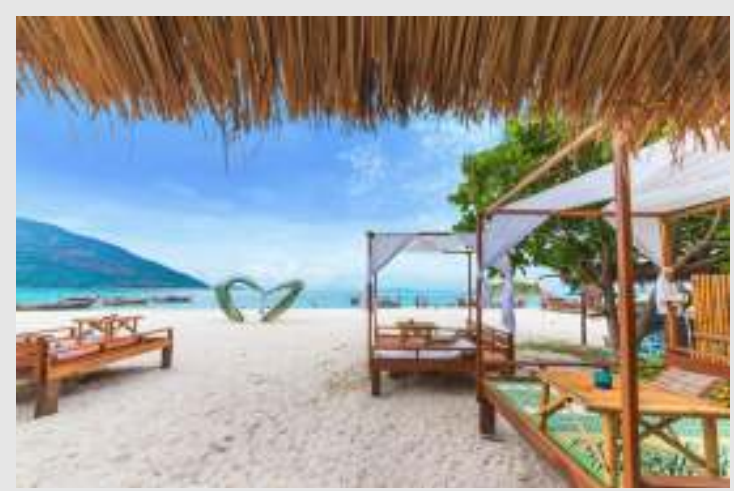

Gambar 3. Usulan ide restauran di pinggir pantai

\section{Membuat spot foto}

Saat ini telah tersedia beberapa spot foto yang menarik seperti Warung Zainab yang ditampilkan pada filem Impian Seribu Pulau. Selain Warung Zainab, tempat penanaman mangrove juga dilengkapi dengan sebuah restoran terapung. Sangat penting bagi wisatawan untuk mengambil foto yang instagrammable. Bila pulau ini menyediakan spot tersebut, maka jelas akan menjadi daya Tarik wisata.

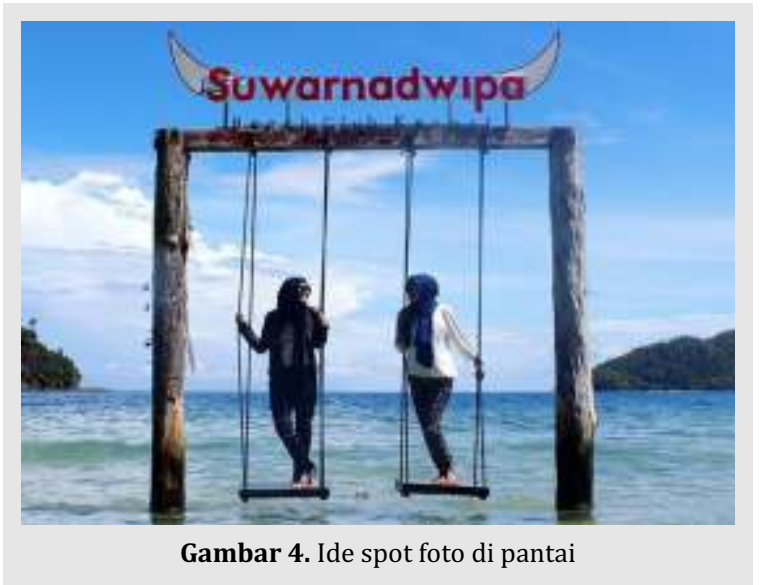


Selain memberikan beberapa ide dan penawaran beberapa peluang model bisnis, program abdimas ini juga mengadakan beberapa pertemuan pelatihan dengan peserta dari penduduk lokal serta pemandu wisata pulau Kelapa.

\section{Pelatihan Service Excellence}

Para pemandu wisata dari pulau Kelapa dan pulau pulau sekitarnya diberikan pelatihan untuk melayani dan memandu wisatawan mancanegara dengan pendekatan eco-tourism dengan pendekatan yang disesuaikan dengan berbagai kultur yang berbeda. Pemandu wisata dibekali dengan video "Cara melayani turis dari Australia, Jepang dan Korea".

Para pemandu diperkenalkan dengan konsep "Service Excellence" serta pariwisata ramah lingkungan dengan konsep Eco-Tourisme melalui wisata menanam terumbu karang, menanam mangrove, serta budidaya penyu.

Para pemandu juga diperkenalkan dengan kiatkiat untuk membina keselarasan alam, dimulai dari menjaga kebersihan serta memelihara keserasian ekosistem laut. Melakukan program daur ulang sampah serta memastikan bahwa pemandu wisata siap mengedukasi wisatawan mengenai konsep pariwisata yang ramah lingkungan.

Kegiatan pelatihan pemandu wisata ini dilaksanakan dalam beberapa tahap di ruang serbaguna Pulau Kelapa dengan melaksanakan pelatihan keterampilan melayani wisatawan dari berbagai negara dan juga sosialisasi mengenai konsep ecotourism. Materi dibagi menjadi tiga sesi sebagai berikut:

1. Sesi pertama: Service excellence untuk turis dari berbagai budaya

Pada sesi ini, dijelaskan mengenai konsep pelayanan paripurna. Penting sekali bagi penyedia pelayanan untuk memberikan kesan yang melebihi harapan dari para wisatawan. Di samping memberikan konsep pelayanan paripurna setiap pemandu wisata juga dilatih untuk melayani berbagai tipe wisatawan yang diperkirakan akan datang. Dalam simulasi di latih penyambutan terhadap wisatawan dari Jepang, Cina, dan Australia.

2. Sesi kedua: Sosialisasi konsep ecotourism dan potensi eko pariwisata Pulau Kelapa

Pada sesi ini, disampaikan pengenalan mengenai konsep ecotourism atau pariwisata yang ramah lingkungan, seperti konservasi penyu laut, pembudidayaan koral, dan penanaman mangrove.

\section{Memberi Pelatihan Marketing Online}

Berdasarkan data 2016, sejumlah 132.7 juta penduduk Indonesia aktif memanfaatkan internet. Ini berarati lebih dari setengah penduduk Indonesia. Bila dilakukan survei terbaru di tahun ini, maka tentunya angka ini akan jauh lebih tinggi lagi. Sebagian besar pengguna ini bermukim di pulau Jawa, dan konsentrasi terpadatnya adalah di ibu kota.

Melihat kecenderungan perilaku masyarakat yang aktif di dunia online ini, tentunya bisa dijadikan sebuah alternative untuk aktivitas marketing secara online. Pengemasan program marketing online ini amat tepat untuk menjual pariwisata Pulau Kelapa.

Di Indonesia social media adalah yang paling sering diakses secara online. Sehingga pemasaran melalui facebook, Instagram, youtube serta berbagai platform online lainnya amatlah efektif.

Dikaji dari referensi yang tersedia, maka terlihat bahwa di jaman globalisasi ini pemasaran online adalah sebuah keniscayaan, oleh karena itu, maka ide yang kami usulkan adalah dengan melakukan beberapa aktivitas marketing melalui sosial media (Utomo, 2015). Saat ini laman social media memang sudah tersedia, namun masih perlu dioptimalkan.

Berdasarkan Analisa terhadap target pasar dari paket wisata pulau ini, maka disarankan untuk melakukan Content Marketing. Cara pemasaran ini dengan merencanakan, membuat dan menyebarkan info pemasaran yang disesuaikan 


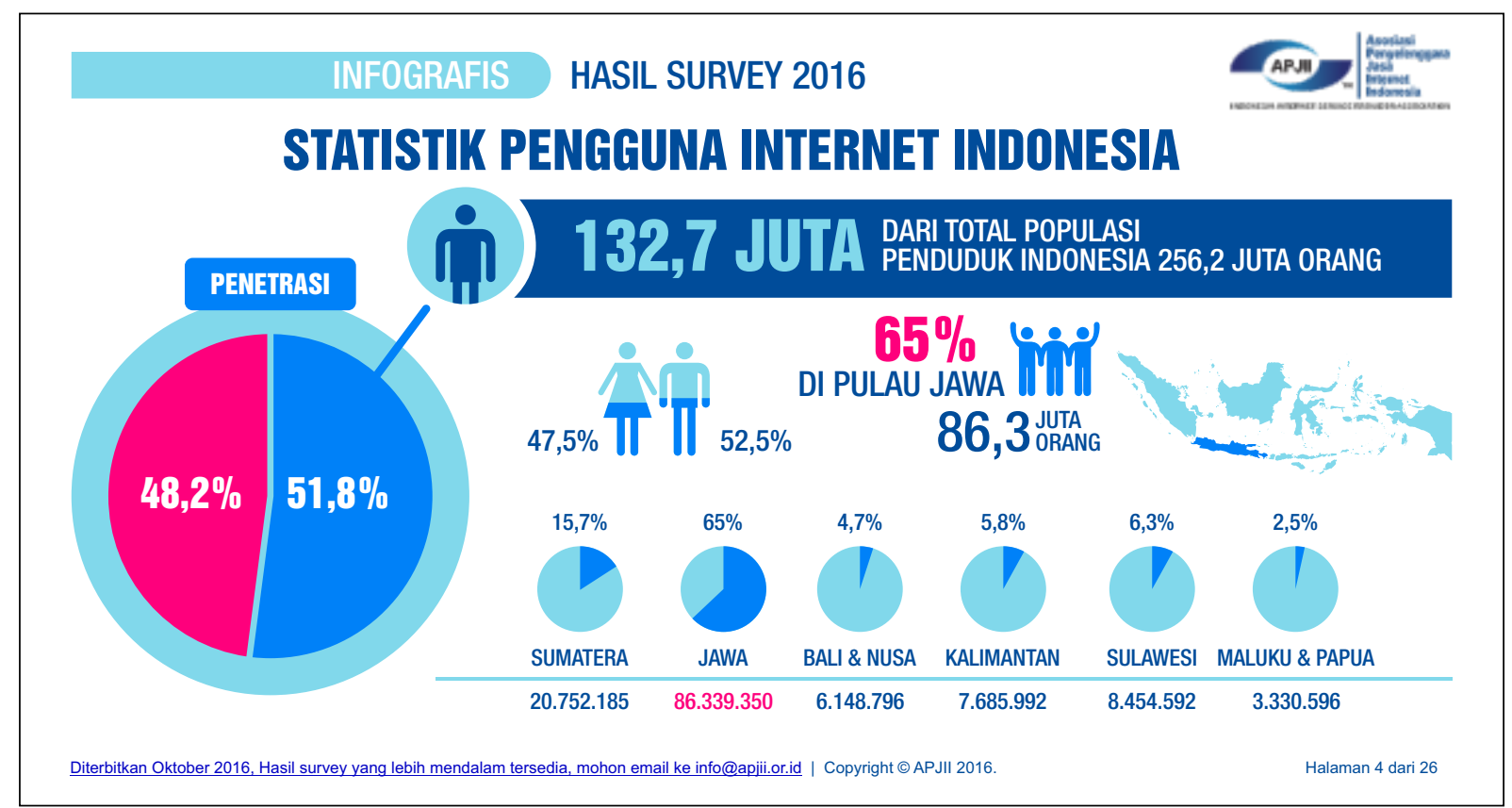

Gambar 5. Statistik Pengguna Internet Indonesia. (Sumber: APJII)

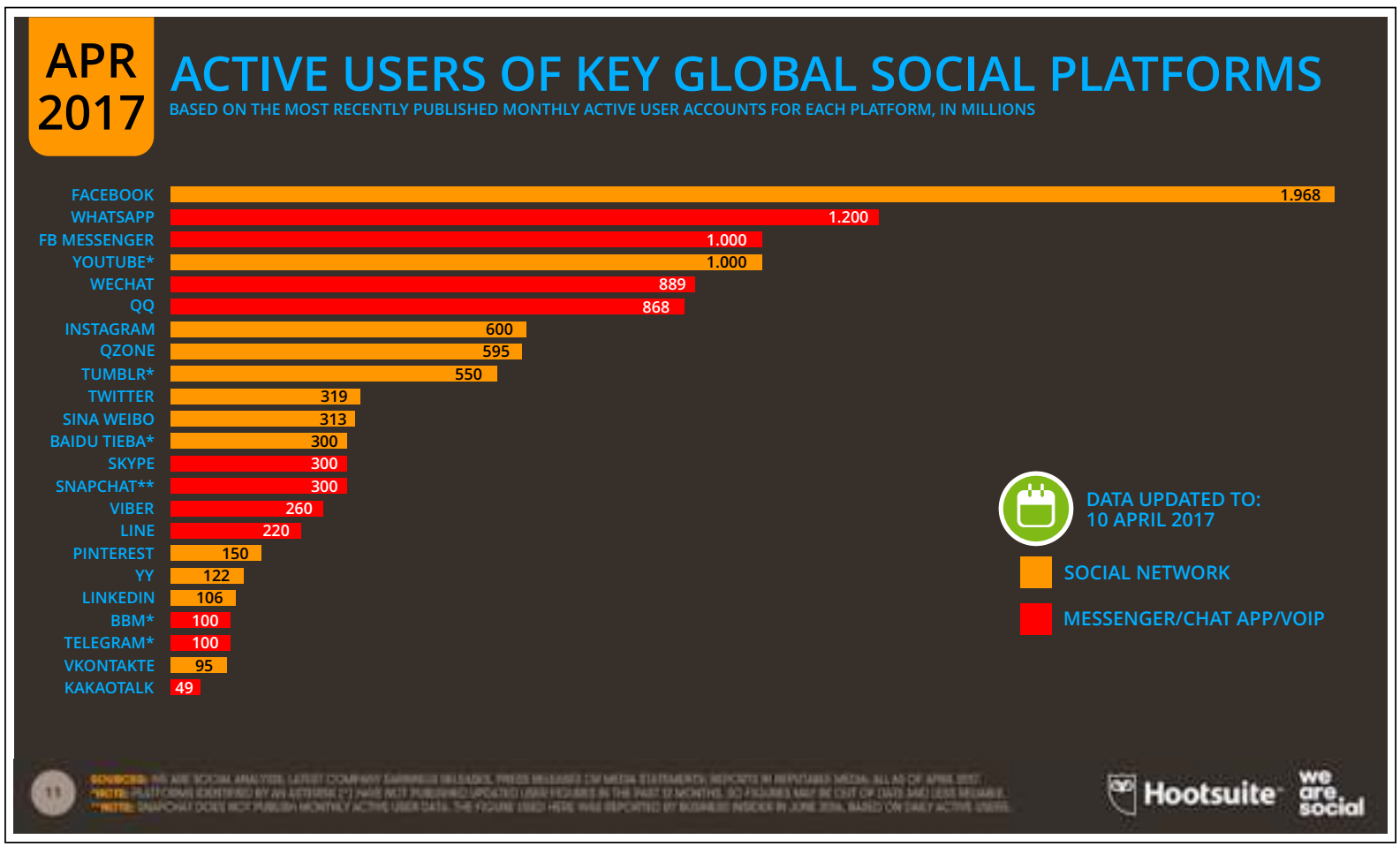

Gambar 6. Pengguna Aktif Platform Sosial secara Global (Sumber: Hotsuite)

dengan target produk yaitu anak-anak muda yang mencari pengalaman serta ingin menjelajahi alam dan menyebarkan pengalamannya melalui social media.

Ada dua sasaran yang didapatkan dari Content Marketing yaitu selain menarik audiens baru untuk mengetahui bisnis yang ditawarkan, juga memotivasi mereka untuk mencoba dan menjadi pelanggan baru.

Untuk tujuan ini Gerakan 1000 bersama koperasi Kinarya telah melakukan pengambilan filem Impian Seribu Pulau, yang berpusat di Puau Kelapa Dua. Para crew filem adalah sepenuhnya remajaremaja termasuk remaja pulau Kelapa Dua yang 
dilatih untuk mengenal sinematografi.

Pada pemutaran file mini telah dirangkul berbagai unsur di masyarakat mulai dari pemerintahan, perusahaan / korporasi, institusi Pendidikan, pelajar/mahasiswa dan menggandeng komunitas serta media. Ke lima unsur ini membentuk kolaborasi Penta Helix. Dengan adanya network yang luas ini, maka melalui filem Impian Seribu Pulau para penonton diperkenalkan dengan kisah dari pulau Kelapa Dua.

Filem ini hanya merupakan pencetus awal, selanjutnya pengalaman wisata di pulau itu sendiri yang akan menjadi bukti pendukung munculnya WOM atau word of mouth. Bila pengalaman yang diperoleh selama berwisata melebihi harapan, maka setiap pengunjung akan menuliskannya di social media masing-masing. Dan paket wisata Kelapa 2 bisa menjadi viral, berkat pengalaman yang diciptakannya.

\section{KESIMPULAN DAN SARAN}

Pengabdian masyarakat ini telah dijalankan mulai dari obsertasi, wawancara, focus group discussion, SWOT analysis hingga pada penyampaian usulan dan pelatihan kepada warga dan komunitas pemandu wisata di pulau Kelapa.

\section{Kesimpulan}

Dari paparan di atas dapat disimpulkan bahwa pulau Kelapa mempunyai potensi untuk pariwisata bahari berbasis budaya Bugis dan juga potensi pariwisata Eco-Tourism, namun untuk membuat potensi ini dapat diangkat menjadi paket wisata yang utuh maka diperlukan perencanaan serta program pengembangan sumber daya manusia yang berkualitas.

Menarik untuk melihat bahwa meski latar belakang Pendidikan mereka rendah, namun animo para penduduk setempat dan pemandu wisata kepulauan seribu menunjukkan tekad yang cukup tinggi. Program pengabdian masyarakat telah menyediakan buku-buku untuk perpustakaan mini bagi warga pulau. Di samping itu juga menyediakan video-video untuk mengenalkan para pemandu wisata mengenai cara penyambutan dan pelayanan kepada wisatawan-wisatawan manca negara.

Program ini dapat berjalan secara berkesinambungan bila kolaborasi penta helix yang terbina di antara komunitas, korporasi, pemerintahan, akademisi serta media terjalin saling mendukung tidak hanya temporer, melainkan berkelanjutan.

\section{Saran}

Kedepannya diperlukan pelatihan dan pendampingan yang lebih berkelanjutan. Upaya ini juga harus ditunjang oleh semua pihak yang terkait. Pada kenyataannya untuk dapat mensuplai ikan/cumi/bahan sea food lainnya untuk restoran /makanan ringan produksi pulau kelasa saja pihak komunitas lokal masih mendapatkan hambatan. Semua tangkapan telah ditampung oleh tauke untuk digunakan oleh pulau-pulau lain yang dikelola secara professional oleh pebisnis berskala besar. Sehingga produksi makanan berbasis seafood merekapun terancam tidak berkelanjutan.

Oleh sebab itu program ini perlu ditunjang oleh berbagai pihak, termasuk Lembaga pemerintahan juga Lembaga non pemerintahan (NGO). Diperlukan suatu jaringan yang saling menopang antara pemerintahan, organisasi nir laba non pemerintahan (NGO) yang peduli, juga ditopang oleh penyedia sarana transportasi laut kepulauan seribu, dan berbagai pihak terkait yang dapat menunjang pengembangan komunitas masyarakat pulau Kelapa. 


\section{DAFTAR PUSTAKA}

Andini, N. (2013). Pengorganisasian komunitas dalam pengembangan agrowisata di desa wisata studi kasus: desa wisata Kembangarum, Kabupaten Sleman. Journal of Regional and City.

Utomo, H. (2015). Menumbuhkan minat kewirausahaan sosial. Jurnal Ilmiah Among Makarti, 7(14).

Feronika, R. F. (2011). Studi Kesesuaian Ekosistem Mangrove Sebagai Objek Ekowisata Di Pulau Kapota Taman Nasional Wakatobi Sulawesi Tenggara. Universitas Hasanuddin. Makassar. 